\title{
Who Engages in Work-Family Multitasking? A Study of Canadian and American Workers
}

\author{
Scott Schieman and Marisa Young
}

\section{Version Post-Print/Accepted Manuscript}

Citation Schieman, Scott and Marisa Young. 2015. "Who Engages in Work(published version) Family Multitasking? A Study of Canadian and American Workers." Social Indicators Research 120(3):741-767.

Publisher's Statement The final publication is available at Springer via https://dx.doi.org/10.1007/s11205-014-0609-7.

\section{How to cite TSpace items}

Always cite the published version, so the author(s) will receive recognition through services that track citation counts, e.g. Scopus. If you need to cite the page number of the TSpace version (original manuscript or accepted manuscript) because you cannot access the published version, then cite the TSpace version in addition to the published version using the permanent URI (handle) found on the record page. 


\title{
Who Engages in Work-Family Multitasking? A Study of Canadian and American Workers
}

\begin{abstract}
This study examines the determinants of work-family multitasking using data from two large national surveys of workers - the 2011 Canadian Work, Stress, and Health Study and the 2002 National Study of the Changing Workforce. We find that the following groups - in both surveysengage in frequent multitasking: (1) individuals with higher education and income; (2) executives and professionals, business owners, the self-employed, and supervisors; (3) those who work at home or some place other than away from home at a fixed location; and (4) those who work long hours, a second job, have job pressure, and receive more work-related contact outside regular work hours, and have more challenging work. Collectively, our findings elaborate on the determinants of multitasking — underscoring the differential and sometimes-unexpected influences of SES, jobrelated demands, resources. Most importantly, our results suggest a remarkable degree of similarity in both the patterns among the determinants and their interrelationships among Canadian and American workers.
\end{abstract}




\section{Who Engages in Work-Family Multitasking? A Study of Canadian and American Workers}

How often do you try to work on job tasks and home tasks at the same time while you are at home? The answers to this straightforward question about "work-family multitasking" provide insights into one of the key sources of stress in everyday life — and their connections to key social roles. Broadly defined, multitasking entails the simultaneous engagement in multiple activities or the often-hurried vacillation between them (Spink, Cole, and Waller 2008). Offer and Schneider (2011) observe that multitasking "allows individuals to squeeze in more tasks and get more things done within a limited amount of time" (p. 810). Some research conceptualizes multitasking in more general terms as involving the combination of a variety of activities like work, housework, childcare, personal care, or transportation (e.g., Offer and Schneider 2011:815). In other instances, multitasking is more specifically linked to the simultaneous engagement of work- and familyrelated activities_-while in the home sphere (e.g., Schieman and Young 2010a; Voydanoff 2007).

In an era of growing pressures faced by many workers, a high degree of multitasking is a significant sign of the times. For example, a 2007 survey found that 33 percent of American workers "sometimes" or "frequently" engage in multitasking (Schieman and Young 2010a; 2010b). Increasingly, workers attempt to blend and blur the border between work and family (Ashforth, Kreiner, and Fugate 2000; Blair-Loy 2003; Hochschild 1997; Jacobs and Gerson 2004). While most probably strive for some degree of "work-family balance" (Clark 2000), role-blurring activities like multitasking present unique challenges to those efforts-especially when strains between work and family roles emerge (Glavin and Schieman 2012; Schieman and Young 2010a). Multitasking can cause problems in the work-family interface - especially when it detracts from attention and energy for family roles, such as childcare, marital relations, and household demands (Voydanoff 2007). Research demonstrates that multitasking can have both positive and negative consequences for role 
functioning, especially conflict between work and family domains (Arendell 2001; Bianchi, Robinson, and Milkie 2006; Glavin and Schieman 2012; Lyness et al. 2012; Offer and Schneider 2011; Sayer 2007a; 2007b; Voydanoff 2005).

Given the potential personal and social consequences of work-family multitasking, it is essential to address a more fundamental issue: Who engages in work-family multitasking? To answer this question, we analyze data from two national surveys of workers - the 2011 Canadian Work, Stress, and Health Study (N=5,809) and the 2002 National Study of the Changing Workforce $(\mathrm{N}=3,484)$. Our main objective is to document the ways that the following factors might influence the likelihood of frequent work-family multitasking: (1) social statuses; (2) employment type; (3) work location and schedule; and (4) job-related demands and resources. We also document and describe the net and indirect influences among these factors. As we will describe below, the patterns and interrelationships observed in both the Canadian and American data are remarkably similar.

\section{WORK-FAMILY MULTITASKING}

\section{Theoretical Perspectives}

Border Theory offers a set of concepts and ideas to guide theorizing and hypotheses about the determinants of multitasking (Ashforth et al. 2000; Clark 2000; Nippert-Eng 1996; Voydanoff 2005). This theory suggests that the border between work and family is characterized along a continuum of complete segmentation to complete integration. In highly segmented contexts, the physical and temporal boundaries reflect distinctive domains — structural arrangements that are akin to the "separate spheres" depiction of work and family, each with different sets of expectations and behaviors (Coontz 1992). At the other end of the continuum, high integration occurs when there is little distinction between work and family roles, especially when and where these roles are enacted and engaged (Nippert-Eng 1996). 
A general prediction from this view-the role blurring hypothesis - posits that the work and family conditions that predict greater integration should also increase role-blurring activities like multitasking (Glavin and Schieman 2012). The question becomes: What factors contribute to greater integration? Border Theory identifies flexibility and permeability as two key influences. "Flexibility" refers to the degree that one's work tasks and responsibilities can be accomplished outside the usual physical and temporal parameters of the workplace - that is, "the extent to which a border may contract or expand, depending on the demands of one domain or the other" (Clark 2000, p. 757). Similarly, "permeability" entails "the degree to which a role allows one to be physically located in the role's domain but psychologically and/or behaviorally involved in another role" (Ashforth et al. 2000, p. 474). Although flexibility and permeability often ease transitions between roles, they may also loosen the work-family boundary in ways that facilitate role-blurring activities like multitasking (Clark 2000; Hill, Hawkins, and Miller 1996; Olson-Buchanan and Boswell 2006). Stated formally, the role-blurring hypothesis predicts more frequent multitasking activities among individuals whose experience reflects greater integration, and among those whose workfamily border is more flexible and permeable.

With these ideas as a backdrop for the general role-blurring thesis, we sharpen our hypotheses by focusing on a specific constellation of work conditions. To do so, we integrate ideas from the Job Demands-Resources (JD-R) model alongside Border Theory's emphasis on the relevance of flexibility and permeability to develop specific hypotheses about the relationship between work conditions and multitasking (Bakker and Demerouti 2007). These work conditions are organized around demands and resources. According to Bakker and Geurts (2004, p. 348):

"Job demands refer to those physical, psychosocial, or organizational aspects of the job that require sustained physical and/or mental effort and are, therefore, associated with certain physiological and/or psychological costs... Job resources refer to those physical, psychosocial, or organizational aspects of the job that may be functional in meeting task requirements (i.e., job demands) and may thus reduce the associated 
physiological and/or psychological costs - and at the same time stimulate personal growth and development."

Based on this definition, the following sections first describe hypotheses that specify how job demands and resources might influence exposure to work-family multitasking. Then, we identify additional hypotheses about the ways that social statuses — especially socioeconomic status (SES) might shape job-related demands and resources in ways that contribute to frequent multitasking.

\section{The Demand Hypothesis}

The basic prediction of the demand hypothesis is that several distinct but interrelated job demands_-job pressure, long work hours, and work contact (defined below)—should be associated with frequent multitasking. In the vast literature on work and stress, job pressure is the quintessential demand (Diestel and Schmidt 2009; Kristensen et al. 2004). This originates from early emphases on workers being required to engage in face-paced and intense activities while navigating time constraints (Karasek 1979; Karasek and Theorell 1990). Themes typically involved the quantity of work, the time to complete it, and the perceptions of its associated pressures. In the present study, workers who report high levels of job pressure experience being overwhelmed by the amount of work they have to do; they must work on too many tasks at the same time; the demands of their job exceed the time they have to do the work. Moreover, feeling a "time squeeze" and pressure correspond with longer work hours (Mattingly and Sayer 2006; Roxburgh 2002; Schieman 2013). In the present study, we assess "long work hours" as (1) working 50 or more hours per week at a main job and (2) working at least 10 hours per week a second job. Taken together, we hypothesize that job pressure and the time pressures associated with long work hours foster role integration and permeability; in turn, such conditions should contribute to work-family multitasking (Schieman and Young 2010a, b; Voydanoff 2007; Wharton and Blair-Loy 2006). 
Alongside overwork and time pressures, we identify a third condition that Voydanoff (2007) labels a "boundary-spanning demand"- the frequency that workers send and receive work-related communications outside of regular work hours (for shorthand, "work contact"). The proliferation of communication technologies has facilitated the ways that work may be completed "any time and any place" (Chesley 2005)—factors that are directly relevant for integration and permeability. Perhaps more than any other job demand, work contact may increase the fluidity of borders and promote the risk of engaging in work tasks simultaneously with other activities (at home). While some research suggests work contact has positive and negative consequences for individuals (Gajendran and Harrison 2007), others emphasize its association with greater work-family multitasking and conflict (Glavin and Schieman 2012; Schieman and Glavin 2008; Schieman and Young 2010a, b; Voydanoff 2007). We extend this prior research by assessing the ways that work contact is associated with multitasking independently of other job-related demands.

\section{The Resource Hypothesis}

Proponents of the JD-R model assert the following: "Job resources reduce job demands and the associated physiological and psychological costs" (Bakker and Demerouti 2007, p. 312; also see Bakker and Geurts 2004; van der Doef and Maes 1999). We propose the resource hypothesis to directly test the first part of this proposition: If job resources do-in practice-“"reduce job demands," then each job resource should be associated with less multitasking. This view derives from earlier ideas about the benefits of job control, which involves the extent that a worker controls the activities, timing, and pace of the work (Karasek 1979). One mechanism that might link job control to less multitasking involves flexibility — a key precursor to "work-life balance" (Golden 2001; Mauno, Kinnunen, and Ruokolainen 2006; MacEachen, Polzer, and Clarke 2008).

Voydanoff's (2005) "boundary-spanning resource” concept is especially relevant for this hypothesis 
because it involves "structural or psychosocial assets that may be used to facilitate performance, reduce demands, or generate additional resources, for example flexibility regarding when and where work activities are performed" (p. 491).

In the present study, we evaluate three forms of job control that scholars have characterized as job-related resources: schedule control, job autonomy, and challenging work. Schedule controlthe attribute most closely linked to the concept of temporal flexibility-involves the capacity to determine the start and end times of one's own work schedule (Kelly and Moen 2007; Lyness et al. 2012). Job autonomy involves the extent that individuals have the freedom to decide when, where, and how their work gets done (Tausig and Fenwick 2011). While schedule control and autonomy align distinctly within the conventional view of "job resources," challenging work also represents an aspect of control that may influence multitasking. Challenging work involves the extent that workers are required to keep learning new things, engage in creative activities, use their skills and abilities, and handle a variety of tasks (Schieman 2013). This concept blends interrelated themes that researchers have referred to with a range of terms, including "complexity," "skill variety," "nonroutine work," “creative work," "skill discretion" "learning possibilities," and "opportunities for professional development" (Bakker and Geurts 2004; Bakker et al. 2010; Hackman and Oldham 1975; Karasek 1979; Mirowsky and Ross 2003). The concept of challenging work parallels the influential Job Demand-Control (JD-C) model's “decision latitude," which underscores the skill discretion and creativity required on the job (Karasek and Theorell 1990). According to Voydanoff (2007), work conditions that foster creativity, skill enhancement and utilization, and problem solving represent resources that help workers navigate stress in the work-family interface. Collectively, we view these ideas of the resource hypothesis through the lens of an exposure argument; it predicts that each of the three job resources should independently be associated with less frequent multitasking. 
Considering an Additional Perspective: The Stress of Higher Status

While the JD-R model and border theory provide a rationale for the demand and resource hypotheses, we also consider an emerging theoretical perspective - the "stress of higher status" - in an effort to elaborate further on these processes and their consequences (Schieman, Kurashina, and Van Gundy 2006; Schieman and Glavin 2008; Schieman, Milkie, and Glavin 2009). One of its central tenets is that people who occupy higher statuses in the workplace - as experienced in the nature of activities and responsibilities — tend to be exposed to more job demands like longer work hours, greater job pressures, and more work contact. However, its second proposition flips the resource hypothesis by proposing that some job resources might tend to function more like demands - this is particularly evident for "flexibility" and its link to integration, permeability, and increased role blurring. Stated more formally, the stress of higher status hypothesis predicts that some higher status positions or job attributes create the conditions that foster more multitasking.

Some prior evidence provides preliminary support for the stress of higher status view. Among large samples of American workers, for example, schedule control and job autonomy have been linked to more frequent multitasking (Schieman and Young 2010a, b; Voydanoff 2005). Similarly, studies document that greater authority is associated positively with job demands (e.g., longer hours, more pressures) that, in turn, elevate the risk for stress in the work-family interface (Bakker et al. 2010; Brett and Stroh 2003; Maume and Bellas 2001; Mirowsky and Ross 2003; Schieman and Reid 2008; Schieman 2013). Likewise, challenging work has been overtly characterized as both a job resource (Valcour 2007) and a job demand (Grotto and Lyness 2010; Hackman and Oldham 1980). A core concern of assertions that depict this "demand" element focuses on the cognitive requirements (e.g., problem solving, decision making, creative thinking) in many contemporary jobs, especially among professionals (Morrison et al. 2005). While there are 
advantages to challenging work (Mirowsky and Ross 2003), challenging work is associated with 'downsides' like longer work hours, greater demands, and work intensification (Bakker et al. 2010; Maume and Purcell 2007; Schieman 2013). In light of these findings, we evaluate if some higher status positions and resources are associated with multitasking in ways that predicted by the stress of higher status hypothesis. Such observations would challenge the characterization of "resources" and theoretical perspectives about their relevance for stress in the work-family interface.

\section{Potential Precursors of Demands and Resources and their Links to Multitasking}

Having established a theoretical basis for the demands, resources, and stress of higher status hypotheses, we now turn our attention to the potential antecedents of the very conditions embedded within each. Here, we identify three likely influences: (1) social statuses; (2) employment type; and (3) work location and schedule. In the sections that follow, we contend that these conditions may influence the likelihood of multitasking because of the ways that they differentially expose individuals to the job-related demands and resources described above.

Social statuses. Sociological research identifies core social statuses as antecedents to the role conditions that generate stressors or resources (Mirowsky 2013); among the most salient are gender, age, and marital, parental and socioeconomic statuses. First and foremost, gender is prominently featured in analyses of the work-family interface (Korabik, McElwain, and Chappell 2008; Steiber 2009). One of the most relevant findings involves the differences between women and men in the frequency of (and reasons for) multitasking, with some evidence that mothers engage in it more frequently than fathers (Bianchi et al. 2006; Bianchi and Wight 2010; Galinsky et al. 2005; Offer and Schneider 2011). Despite women's increasing participation in the paid labor force, there is evidence that — even when they are engaged in fewer actual hours of paid work - women continue to bear a disproportionate burden of the household physical and mental labor (Arendell 
2001; Bianchi et al. 2006; Coltrane 2000; Craig and Bittman 2008; Presser 1994; Milkie and Peltola 1999; Zick and Bryant 1996). Moreover, women tend to be more likely than men to intermix both housework and childcare with other activities (Bianchi et al. 2006; Craig 2006; 2007; Ironmonger 2004; Lee and Waite 2005; Sayer 2007a; 2007b). The demands of parental responsibilities may be among the most salient influences on multitasking, especially given the extent of time and energy it often requires (Bianchi et al. 2006; Moen and Yu 2000). Within each of these demanding contexts, it is plausible to suspect that women have encountered a disproportionate share of the load and its impact because of processes associated with "intensive parenting"- as parents seek to engage their children in highly active and engaging ways that promote development (Arendell 2001; Hays 1996; Lareau 2003; Nelson 2010).

We also expect that age and socioeconomic status (SES) predict multitasking activities because of their links to work conditions. For example, older workers tend to occupy higher status positions, earn more income, and work longer hours—-factors that have been linked to more frequent role blurring (Boswell and Olson-Buchanan 2007; Duxbury, Lyons, and Higgins. 2008; Glavin and Schieman 2013; Schieman and Glavin 2008). Likewise, one of the emerging patterns in research on the work-family interface involves greater work-family role blurring activities, interference, or conflict among individuals with higher levels of education or income (Hill et al. 2001; Schieman and Glavin 2008; 2011; Schieman et al. 2009; Schieman et al. 2006). This is partly attributed to the nature of the job or the work conditions — especially longer hours and more pressures among those with higher status (e.g., executives and professionals) and greater authority (Jacobs and Gerson 2004; Schieman 2013). Collectively, these points underscore the importance of accounting for the possibility that each of these social statuses and demographic factors; we therefore include them to more accurately assess the net influences of work conditions. To reiterate, our primary objective is to evaluate the ways that work conditions are associated with multitasking 
independently of these statuses and demographics. As we detail below in our "plan of analyses," our base model first establishes the basic patterns of multitasking across gender, age, marital, and parental status, and SES before assessing the impact of demands and resources.

Employment type. As potential precursors to the job-related demands and resources, we evaluate the relevance of conditions that are somewhat more representative of structural features of work. The first set includes comparisons between individuals in higher status occupations (e.g., executive or professional versus technical, service, sales, administrative, or production), wage and salaried employees who work for someone else versus business owners who employ others or independent self-employed workers who do not employ anyone. In addition, having greater authority at work includes supervisory control over others' activities (Carayon and Zijlstra 1999; Elliott and Smith 2004). Smith (2002) explicitly describes authority as a "highly coveted workplace resource" (p. 511), a characterization that is partly due to its positive link with other conditions such as autonomy, schedule control, pay, and advancement (Kalleberg 2011; Reskin and Ross 1992).

Work location and schedule. The second set includes work location (e.g., away from home at a fixed location versus at home or another work location) and schedule (e.g., a regular daytime shift versus a night, rotating/split, or flexible/variable shift). According to MacEachen and colleagues (2008), "modern flexible work is characterized by non-standard working hours, varied workspaces including the home and 'the road,' and flat organizational hierarchies that invite work autonomy and decision-making responsibility" (p. 1019-1029). These qualities share elements of "flexibility" and are often associated with other job-related resources in the JD-R model such as autonomy, decision-making responsibility, and variability in where and when work is performed (Baxter and Kroll-Smith 2005). While such arrangements undoubtedly overlap with other jobrelated resources, no studies (to our knowledge) have explicitly assessed their relevance for multitasking alongside other resources within the framework of the JD-R model. Some scholars 
have characterized flexible work shifts and variable work locations as "non-standard work" because such arrangements deviate from the "standard" employment of the full-time employee who works a regular daytime shift away from home at a fixed location (Kalleberg 2011; Vosko 2000). In this regard, it is plausible that "flexible work" might also reflect work that is considered demanding, insecure, or precarious, and, in turn, increases exposure and vulnerability to stressors at work and home (Craig and Powell 2011; Kalleberg 2011; Mills and That 2010; Tausig and Fenwick 2011).

Taken together, the different ways of conceiving flexible work arrangements present complicated sets of predictions about their connections to multitasking and its consequences. On one hand, we might expect that flexible arrangements provide greater freedom, autonomy, and control that enables workers to limit the extent that work-related tasks permeate the family domain, thereby minimizing work-family multitasking (Golden 2001; Hill et al. 2010; MachEachen et al. 2008; Mauno et al. 2006; Redman, Snape, Ashurst 2009). In this way, flexible arrangements may function in ways predicted by the resource hypothesis. Alternatively, however, the temporal and spatial parameters of work — attributes often associated with "flexibility" - may be among the most important determinants of multitasking. That is, having flexible shifts and working at locations other than a central, fixed location might contribute to the perceived or actual need for more frequent multitasking (Darrah, Freeman, and English-Lueck 2007; Medalia and Jacobs 2008; Schneider and Waite 2005). From this view, flexible work arrangements should tend to function in a manner predicted by the demands hypothesis.

MacEachen and colleagues (2008) provide a rich qualitative account of the question of whether flexible work arrangements function more like resources or demands - or predict exposure to these conditions. Their research demonstrates the ways that managers have both favorable and unfavorable views of flexibility. While the 'upsides' reflect greater freedom and autonomy, the managers' discourse was filled with less positive characterizations - and ultimately lead to the 
conclusion that "flexibility in practice is double-edged, as its link with personal autonomy and freedom blurs boundaries between home and work and creates the conditions and possibility for unlimited work hours" (p. 1023). Given the complicated nature of both work location and schedules, we evaluate if these conditions pattern exposure to demands and resources in ways that contribute to any observed associations between work location/schedule and frequent multitasking.

\section{METHODS}

\section{Samples}

To test the hypotheses outlined above, we analyze data from two sources: the 2011 Canadian Work Stress and Health study (CAN-WSH) and the 2002 National Study of the Changing Workforce (NSCW). The CAN-WSH study is a nationally representative sample of the Canadian labor force. Interviews were conducted by telephone between January and August 2011. To be eligible to participate in the study, individuals had to be: (1) residing in Canada; (2) 18 years of age or older; (3) currently working at a paid job or operated an income-producing business; (4) employed in the civilian labor force; and 5) live in a non-institutional residence. In households with more than one eligible person, we used the "next birthday" method to randomly select a study participant. Generally, this method requires that if there is more than one eligible participant in the household, the person with the next closest birthday will be selected for the interview. Calls were made to a regionally stratified unclustered random probability sample generated by random-digitdial methods. Interviews were conducted in English or French and averaged approximately 30-35 minutes. Study participants were offered a \$20 gift card for completing the interview. The final full sample was 6,004, with a response rate of approximately 40 percent. ${ }^{1}$ All analyses are weighted

\footnotetext{
${ }^{1}$ Some readers might have concerns about the response rate. Although a potential problem associated with lower response rates is nonresponse bias in estimates (Babbie 2007), recent research has challenged the link between response rates and nonresponse bias (see Groves 2006; Curtin, Presser, and Singer 2000; Merkle and Edelman 2002).
} 
according to the most recent Canadian Census information on the gender, age, marital status, and education profile of the population. Based on this weight and exclusions of participants with missing values on focal measures, our analytical sample includes 5,809 cases.

The NSCW is a nationally representative sample of 3,504 individuals in the U.S. labor force. To be eligible to participate in the study, individuals had to be: (1) residing in the contiguous 48 states; (2) 18 years of age or older; (3) currently working at a paid job or operated an incomeproducing business; (4) employed in the civilian labor force; and 5) live in a non-institutional residence. Study participants were interviewed by telephone between October 2002 and June 2003. Study participants were offered a \$25 cash honoraria for completing the interview. Calls were made to a regionally stratified unclustered random probability sample generated by random-digit-dial methods. A response rate of approximately 52 percent of potentially eligible households yielded the full sample (see Bond et al. 2003). All analyses are weighted by the number of eligibles in the respondents' households and then proportions in the March 2002 Current Population Survey for eligibles per household, eligible men and women, and eligibles with different educational levels. Based on this weight and exclusions of participants with missing values on focal measures, our analytical sample includes 3,484 individuals.

\section{Measures}

Work-family multitasking. In both the CAN-WSH and NSCW, information on work-family multitasking was gathered by asking study participants: "How often do you try to work on job tasks and home tasks at the same time while you are at home?" We coded "never" or "rarely" responses

Nevertheless, we address the possibility that results were unduly influenced by nonresponse bias. In order to do this, we compared results from unweighted and weighted analyses in which we weighted the sample based on a key set of demographic statuses (e.g., gender, age, marital status, education) from the 2006 Canadian Census. We found few differences between the weighted and unweighted results. Winship and Radbill (1992) argue that controlling for characteristics on which individuals may be under- or over-sampled adjusts for biases due to these characteristics; all of our analyses include a set of controls to adjust for this potentiality. 
as 0 and "sometimes," "often," and "very often" as 1 . While we acknowledge that multiple-item measures are ideal, it should be noted that the developers of the 2002 NSCW specifically designed this single item to assess multitasking. Moreover, analyses that have since used this single-item measure have appeared in recently published research on the work-family interface (Schieman and Young 2010a; Voydanoff 2005; 2007; see Schneider 2009, for a review of work-family measures).

Gender. We use dummy codes for men (0) and women (1).

Age. Age is coded in years.

Married. Individuals who are married or living with a partner are coded 1, all others 0.

Children at home. We include the number of children younger than age 18 living at home.

Education. Education contrasts "high school or GED" with "less than high school," “associate/2-year degree," "some college, no degree earned," "4-year university degree,” or "graduate or professional degree (MA/Ph.D.)"

Personal income. One item assesses personal earnings in the previous year from all sources with the following categories: " $\$ 25,000$ or less," "\$25,001 to $\$ 50,000, "$ " $\$ 50,001$ to $\$ 75,000, "$ “\$75,001 to $\$ 100,000, "$ " $\$ 100,001$ or more." We use $\$ 25,001$ to $\$ 50,000$ as the reference group.

Employment type. To assess whether or not the participant is in a higher status occupation, the following question was asked: "What kind of work do you do? That is, what is your occupation?" Using the open-ended information provided, we coded higher status occupation ("executive" or "professional") with a category that combines all others ("technical," "service," "sales," "administrative" and "production"). We also compare individuals who are "wage and salaried employees who work for someone else" with two other groups: "business owners who employ others" and "independent self-employed workers who do not employ anyone." To assess supervisor status, we also compare individuals who reported that they supervise other workers as part of their job (coded $1=$ "supervisor") with those who do not supervise others (coded 0 ). 
Work location/schedule. We assess individuals' work location by contrasting those who "work mainly away from home at a fixed location" (the reference category) with individuals who work "mainly at home" or "mainly at various client or customer locations, on the road, or some other location." To measure work schedule, we contrast those with "a regular daytime shift" (the reference category) with the following other options: "night or evening shift," "rotating or split shift," "flexible or variable schedule with no set hours (e.g., on call)," or some other shift that is not specified in these other options.

Long work hours. We compare individuals who work 50 hours or more per week (coded 1) with all others (coded 0$)$.

Second job. We compare individuals who work at least 10 hours in a second job (coded 1) with those who do not (coded 0).

Job pressure. In the CAN-WSH, three items ask about the frequency in the past three months of the following: "Felt overwhelmed by how much you had to do at work?" "Have to work on too many tasks at the same time?" "The demands of your job exceeded the time you have to do the work?" Response choices are coded: "never" (1), "rarely" (2), "sometimes" (3), "often" (4), and "very often" (5). We averaged the items to create the index; higher scores indicate more job pressure $(\alpha=.85)$. These items are similar to those used in other previously published research on related themes like "pressure," "work-load," or "quantitative demands" (Carayon and Zijlstra 1999; Harmä 2006;" Kristensen et al. 2004; van den Broeck et al. 2010). Similarly, in the NSCW, participants were asked the following three items about their main job: "How often have you felt overwhelmed by how much you had to do at work in the past three months?" "During a typical workweek, how often do you have to work on too many tasks at the same time?" "I never seem to have enough time to get everything done on my job." Response choices for the first two items are coded: "never" (1), "rarely" (2), "sometimes" (3), "often" (4), and "very often" (5). Response 
choices for the third item are coded: "strongly disagree" (1), "somewhat disagree" (2), "somewhat agree" (3), "strongly agree" (4). We standardized the items because of the different response choices and averaged the items to create the index; higher scores indicate more pressure $(\alpha=.73)$.

Work contact. In the CAN-WSH, the frequency of work contact is based on responses to three items: "How often were you called about work-related matters when you were not at work?" "How often did you read job-related email or text messages when you were not at work?" "How often did you contact people about work-related matters when you were not at work?" Participants were asked to consider the occurrence of these activities during the past 3 months: "never" (1), "rarely" (2), "sometimes" (3), “often" (4), and "very often" (5). Responses are averaged to create the index; higher scores indicate more contact $(\alpha=.78)$. In the NSCW, one item assesses the frequency that individuals are contacted for work-related reasons outside of normal work hours: "How often do coworkers, supervisors, managers, customers, or clients contact you about workrelated matters outside normal work hours? Include telephone, cell phone, beeper and pager calls, as well as faxes and e-mail that you have to respond to." Response choices are "never" (1), “occasionally" (2), "fairly regularly but less than once a week" (3), “once a week" (4), "several times a week" (5), “once a day" (6), "several times a day" (7), and “many times a day" (8).

Schedule control. In both the CAN-WSH and NSCW, the following question asked participants: "How much control do you have in scheduling your work hours?" Response choices are coded: "none" (1), "very little" (2), "some" (3), "a lot" (4), and "complete control" (5).

Job autonomy. In both the CAN-WSH and NSCW, three items ask the extent that study participants agree or disagree with the following statements: "I have the freedom to decide what I do on my job," "It is basically my own responsibility to decide how my job gets done," and "I have a lot of say about what happens on my job" (see Grotto and Lyness 2010; Thompson and Protta 2006). Response choices are coded "strongly disagree" (1), "somewhat disagree” (2), "somewhat 
agree" (3), and "strongly agree" (4). We averaged responses to create the job autonomy index; higher scores reflect more autonomy (CAN-WSH, $\alpha=.78$; NSCW, $\alpha=.72$ ).

Challenging work. In the CAN-WSH and NSCW, five items measure challenging work. The first four items are identical in the two surveys: "My job requires that I keep learning new things," "My job requires that I be creative," "My job lets me use my skills and abilities," and "The work I do on my job is meaningful to me." The fifth item is "My job requires that I do the same things over and over again" in the NSCW and "I get to do a lot of different things on my job" in the CANWSH. Response choices are coded: "strongly disagree" (1), "somewhat disagree" (2), "somewhat agree" (3), and "strongly agree" (4). We averaged responses to create the index; higher scores reflect more challenging work (CAN-WSH, $\alpha=.78$; NSCW, $\alpha=.67$ ). Collectively, these items blend interrelated themes that have been referred to as "creative work," "nonroutine work," "skill utilization," "learning possibilities," or "opportunities for professional development" (Bakker and Geurts 2004; Bakker et al. 2010; Bakker et al. 2003; Hackman and Oldham 1975; Mirowsky and Ross 2003; Schieman and Young 2010b).

\section{Plan of Analyses}

Because our dependent variable is dichotomous, we use logistic regression for analyses. First, model 1 in Table 1 tests the base model for social status and demographic variables (gender, age, married, children, education, and income). Subsequent models separately include the following sets of variables: (2) employment type and work location/schedule; (3) job-related demands (pressure, long hours, second job, work contact); (4) job-related resources (schedule control, autonomy, and challenging work); (5) all sets of variables simultaneously. We test these models first using the CAN-WSH data and then assess if they replicate in the NSCW. The progressive adjustments in these models mirror the logic described by Mirowsky (2013). Our 
decision to enter variables in these particular sets is motivated by an interest in their independent contributions to multitasking as well as their net influences after having accounted for the others. This analytical approach can help explain previously observed associations or reveal suppressed effects in which coefficients change direction or become stronger (Mirowsky 2013; Schieman 2010). Table 1 provides descriptive statistics for all study variables in both samples.

\section{[INSERT TABLE 1 ABOUT HERE]}

\section{RESULTS}

Findings from the Canadian Work, Stress, and Health Study

The based model (1) indicates that, among the social status and demographics, only the number of children, education, and income are significantly associated with a greater likelihood of frequent multitasking. Relative to those with a high school degree (the reference group), individuals in the two highest education categories are more likely to report frequent multitasking. Likewise, individuals in the three highest income brackets report a greater likelihood of multitasking compared to those earning between $\$ 25,000$ and $\$ 50,000$ (the reference group). The darker bars in Figures 1 and 2 illustrate the predicted probabilities of frequent multitasking across levels of education and income prior to the inclusion of other conditions in subsequent models.

\section{[INSERT TABLE 2 AND FIGURES 1 AND 2 ABOUT HERE]}

Model 2 shows that executives and professionals are significantly more likely to multitask compared to those in other occupation categories (e.g., sales, service). Similarly, business owners and the self-employed multitask more frequently than wage-and-salaried employees; supervisors are also more likely to multitask than non-supervisors. Figure 3 shows the different predicted probabilities for supervisors versus non-supervisors prior to the inclusion of job-related demands and resources in subsequent models. Here, we have chosen to only illustrate the patterns for 
supervisor status because, as subsequent models will demonstrate, it is the lone factor among the employment type set that becomes statistically non-significant once we adjust for job demands.

\section{[INSERT FIGURE 3 ABOUT HERE]}

As model 2 shows, individuals who work at home or some other location experience a greater likelihood of multitasking compared to those who work mainly away from home at a fixed location. Likewise, those who work a flexible/variable shift report higher odds of frequent multitasking compared to those who work a regular daytime shift. The inclusion of employment type and work location/schedule reduces the size of the odds ratios for education and income, although both remain statistically significant; the largest reductions occur at the very highest levels of education and income. Separate analyses (not shown) indicate that these reductions are mainly due to the fact that the most educated and highest earners are significantly more likely to hold higher status occupations, own businesses, and supervise others - and each of these conditions are in turn associated with frequent multitasking.

In model 3, each of the job demands - long work hours, working additional hours at a second job, job pressure, and work contact — are independently associated with frequent multitasking. Moreover, the inclusion of job demands contributes greatly to the SES-based differences. Comparing models 2 and 3, education-based differences are substantially reduced and the income-based differences disappear altogether. With adjustments for job demands, we also detect reductions in the odds ratios for executive/professional, business owners, and supervisorsindicating that these employment types and positions are associated with greater demands, which, in turn, contribute to frequent multitasking. In fact, the difference in frequent multitasking between supervisors and non-supervisors becomes non-significant. Taken together, these patterns demonstrate the ways that higher SES is linked to multitasking indirectly via its positive association with job demands. Canadian workers with more education, income, and supervisory authority at 
work multitask more frequently because of their greater exposure to demands. Separate analyses indicate that the bulk of these effects are attributable specifically to job pressure and work contact.

Among the three job-related resources shown in model 4, only challenging work is associated with frequent multitasking; schedule control and job autonomy are unrelated to multitasking. Moreover, a comparison of models 2 and 4 shows that job-related resources have little impact on the previously described effects. And finally, model 5 shows mostly independent influences of demands and resources on multitasking. Collectively, the underlying story is that the positive associations between each of the job demands and multitasking hold and are largely independent of resources. Moreover, job-related demands have a stronger and more consistent explanatory impact compared to job resources on the effects of education, income, employment type, and work location/schedule. The lighter bars shown in Figures 1 - 3 illustrate a flattening of the education-, income-, and supervisor status-based differences in the probability of frequent multitasking. Interpreted another way, were all things (i.e., job demands) equal across education, income, and supervisor status, we would see little difference in multitasking across these statuses. However, all things are not equal: the well-educated, higher earners, and supervisors report significantly higher levels of job pressure and work contact - and these patterns, in turn, contribute to their elevated risk of frequent multitasking.

\section{Findings from the 2002 National Study of the Changing Workforce}

With a few exceptions, the findings among American workers reported in Table 3 mostly mirror those that we reported in Table 2 for the Canadian sample. Model 1 in Table 3 shows that among the social statuses and demographic variables, only education and income are significantly associated with frequent work-family multitasking. Specifically, relative to those with a high school degree (the reference group), individuals in the lowest and two highest education categories are 
more likely to report frequent multitasking. Likewise, individuals in the three highest income brackets report a greater likelihood of multitasking compared to those earning between $\$ 25,000$ and $\$ 50,000$ (the reference group). It is noteworthy how highly similar the odds ratios for the effect of education are to the US data (e.g., college degree CAN $=1.700$ versus $\mathrm{US}=1.777$; graduate degree $\mathrm{CAN}=2.713$ versus US $=2.677)$. One finding is quite different: Among Americans with less than high school report more frequent multitasking deviates from the Canadian pattern. In addition, the income-based gradient in multitasking is somewhat less steep in the Canadian sample relative to the American data.

\section{[INSERT TABLE 3 ABOUT HERE]}

In model 2, we observe that executives and professionals are significantly more likely to multitask compared to individuals in other occupation groups. Likewise, business owners who employ other people and the self-employed are more likely to multitask compared to wage-andsalaried employees; supervisors are also more likely to multitask than non-supervisors. In terms of work location and schedule, we observe that compared to individuals who work mainly away from home at a fixed location, those who work at home or some other locations (e.g., clients, on the road) are more likely to multitasking. And, those who work a flexible or variable shift report more multitasking than those who work a regular daytime shift. The inclusion of employment type and work location/schedule reduces the size of the odds ratios for college and graduate degrees, and the income group comparisons, although each remains statistically significant. As we showed in the Canadian data, the largest reductions in the size of the coefficients occur at the very highest levels of the education and income. Separate analyses (not shown) indicate that these reductions are mostly attributable to the fact that the well-educated and higher earners are more likely to hold higher status occupations, own businesses that employ others, and supervise others on the job. 
In model 3 of Table 2, each of the job demands-long work hours, working a second job, pressure, and work contact—are independently associated with frequent multitasking. Moreover, the inclusion of these demands has implications for the size of the effects reported in the model 2. First and foremost, the inclusion of job demands substantially accounts for the SES-based differences observed in model 1. Most notably, the income-based differences that we observed in model 2 disappear altogether in model 3. Similarly, education-based differences are substantially reduced. We also observe substantial reductions in the coefficients for owners, the self-employed, and supervisors - indicating that each of these positions is associated with greater demands, which, in turn, contribute to frequent multitasking. Taken together, these patterns demonstrate the ways that higher SES is linked to multitasking indirectly via its connections to job demands. Separate analyses indicate that most of these mediating effects are due to job pressure and work contact. Model 4 demonstrates that each of the job resources—schedule control, autonomy, and challenging work — have different associations with multitasking. For example, schedule control is associated with lower odds of multitasking; challenging work is associated with greater odds of multitasking; and job autonomy is unrelated to the odds of multitasking. Moreover, a comparison of models 2 and 4 shows that job-related resources have little impact on the SES and employment type effects. It is quite evident that job-related demands have a substantially greater-and more consistent — explanatory role than job-related resources. In the final model (5) we include all variables to evaluate the net influences of demands and resources on multitasking. This reveals some overlap, but the independent influences of demands and resources on multitasking are most evident. Collectively, the underlying story is that the positive associations between each of the job demands and multitasking hold and are largely independent of resources. 


\section{DISCUSSION}

Three main contributions emerge from our study. First, we document a comprehensive set of patterns that illustrate the ways education and income increase the risk of work-family multitasking. Moreover, these SES-based patterns are largely due to the ways that they co-occur with particular employment types, work locations, and job-related demands. One prominent pattern entails the ways that both education and income are initially associated with more frequent multitasking — but those effects are largely attributable to the ways that these SES resources share their influence with job demands. The findings in the first section of our analyses provide clear evidence to support the basic prediction of the demand hypothesis: job pressure, long work hours, and work contact are each independently and positively associated with multitasking. By contrast, our observations challenge the foundation of the resource hypothesis: Of the job resources, only challenging work is independently associated with more frequent multitasking. (Recall that the resource hypothesis, which is based on the core tenets of the JD-R model—explicitly predicts that resources should be associated with less multitasking.) Moreover, once we account for demands, the pattern of net effects of job resources provides support for the stress of higher status hypothesis. That is, resources are associated with greater multitasking partly because of their association with more demands. Collectively, these patterns raise questions about the conceptualization and theoretical predictions regarding "resources," especially as they relate to various forms of demanding work.

The ways that challenging work and supervisory authority link with more frequent multitasking seem to parallel the concept of "responsible autonomy" and its consequences for demanding work (Economist 2006; Frenkel et al. 1995). Although directives might come from superordinates (i.e., managers), for instance, individuals are often given more latitude about the nature of the work and how to attain objectives (Newell et al. 2002) — a set of managerial practices with more "coordinate and cultivate" and "visionary guidance" characteristics than "command and 
control" or "direct monitoring" (Allvin and Aronsson 2003; Malone 2004). Ultimately, these types of dynamics are purported to enhance "innovation, creativity, and dedication" (MacEachen et al. 2008, p. 1021), and further promote competitiveness (Adkins 2005; Green 2005). Themes of authority and challenging work are reflected here in the concept of the "ideal worker"- one expected to engage in role blurring activities in ways that privilege the expectations and duties of work (Amar 2002). Our results bolster this case by documenting interrelationships among these job resources and a set of associated demands like long hours, pressure, and work contact (Heisz and LaRochelle-Cote 2006; Schieman 2013). Higher status expectations - to be "competitive" and “enterprising" — often demand more time, energy, and attention from workers; indeed, these dynamics are identified as part of the reason why stress is a major concern in flexible knowledge work contexts and their implications for problems at the work-family border.

Collectively, these work conditions identify ways that heightened work intensity might encourage more work-family multitasking. Moreover, the patterns build further support for the first core tenet of the stress of higher status hypothesis, which flips the resource hypothesis by proposing that some job resources function more like demands. In these processes, people who occupy higher statuses in the workplace (as experienced in the nature of activities and responsibilities) ultimately experience more frequent multitasking. However, this is only the first part of the stress of higher status thesis.

In addition to these main contributions of our study, we wish to acknowledge a few potential limitations. First, these data are based on the first wave of a planned multi-wave effort. Therefore, it is limited by the cross-sectional design. While we make some assumptions about causal processes based on the JD-R model and border theory, as well as relevant empirical evidence, we recognize that longitudinal data would more accurately represent the focal relationships. The findings reported here should therefore be viewed as a preliminary baseline upon which further more elaborate and 
nuanced patterns can be developed and tested. Second, the single-item measure of work-family multitasking may be viewed as a shortcoming. Respondents were asked to report how often they engage in work- and family-related tasks simultaneously while they are at home. It should be noted that this item is derived from the National Study of the Changing Workforce - a highly respected data source. In addition, others have tested and validated the single item measure in recently published articles and books (see Schieman and Young 2010a; Voydanoff 2005, 2007). Nonetheless, we recognize that a single item measure has its limits and might not fully capture the underlying construct. Given these concerns, we will begin to conduct a series of in-depth qualitative interviews with these study participants to learn more about the nature, meaning, and appraisals of work-family multitasking activities. However, we will use the insight gained from the preliminary portrait in the present study as a starting point for our understanding of this complex construct.

In the Introduction of this paper, we framed our analyses around research questions about the determinants of work-family multitasking. Collectively, our observations provide new insights into one of the key sources of stress in everyday life — one that remains largely unexamined in the work-family literature. Moreover, we situate this question within the context of its connections to a comprehensive range of work conditions. We build directly upon previous evidence from the American context with new data from a large national sample of Canadian workers, demonstrating the ways that multitasking activity — an important form of role-blurring and influence on stress in the work-family interface-is not randomly distributed in the population. Rather, we have shown how it is linked in complex and sometimes-unexpected ways to a range of work conditions, especially job demands and resources. Moreover, our observations of the determinants and contingencies provide novel tests of the demand, resource, and stress of higher status hypothesesand elaborate on the intricacies of each. 


\section{REFERENCES}

Adkins, L. (2005). The new economy, property and personhood. Theory, Culture \& Society, 22, $111-130$.

Ahrentzen, S. B. (1990). Managing conflict by managing boundaries: How professional homeworkers cope with multiple roles at home. Environment and Behavior, 22,723-752.

Aiken, L. \& West, S. 1991. Multiple regression: Testing and interpreting interactions. Thousand Oaks, CA: Sage.

Allvin, M. \& Gunnar, A. (2003). The future of work environment reforms: Does the concept of work environment apply within the new economy? International Journal of Health Sciences, $33,99-111$.

Amar, A. D. (2002). Managing knowledge workers: Unleashing innovation and productivity. London: Quorum Books.

Arendell, T. (2001). The new care work of middle class mothers: Managing childrearing, employment, and time. In K. J. Daly (Ed.), Minding the Time in Family Experience: Emerging Perspectives and Issues, Vol. 3 (pp. 163-204). Oxford, UK: Elsevier.

Ashforth, B, E., Kreiner, G., \& Fugate, M. (2000). All in a day's work: Boundaries and micro role transitions. Academy of Management Journal, 25:472-491.

Aumann, K., Galinsky, E., \& Matos, K. (2011). The new male mystique. Families and Work Institute. http://familiesandwork.org/site/research/reports/newmalemystique.pdf. Accessed 14 November 2012.

Babbie, E. (2007). The practice of social research, 11th edition. Belmont, CA: Wadsworth.

Bakker, A. B. \& Demerouti, E. (2007). The job demands-resources model: State of the art. Journal of Managerial Psychology, 22, 309-328. 
Bakker, A. B. \& Geurts, S. (2004). Toward a dual-process model of work-home interference. Work and Occupations, 31, 345-366.

Bakker, A. B., Boyd, C. M., Dollard, M., Gillespie, N., Winefield, A. \& Stough, C. (2010). The role of personality in the job demands-resources model: A study of Australian academic staff. Career Development International, 15, 622-636.

Bakker, A. B., Demerouti, E., De Boer, E. M., \& Shaufeli, W. B. (2003). Job demands and job resources as predictors of absence duration and frequency. Journal of Vocational Behavior, $62,341-356$.

Batt, R. \& Valcour, M. (2003). Human resources practices as predictors of work-family outcomes and employee turnover. Industrial Relations, 42, 189-120.

Baxter, V. \& Kroll-Smith, S. (2005). Normalizing the workplace nap: Blurring the boundaries between public and private space and time. Current Sociology, 53, 33-55.

Bellavia, G. M. \& Frone, M. (2005). Work-family conflict. In J. E. Barling, K. Kelloway \& M. R. Frone (Eds.), Handbook of work stress (pp. 113-148) Thousand Oaks, CA: Sage.

Bianchi, S. M. \& Wight, V. R. (2010). The long reach of the job: Employment and time for family life. In K. Christensen \& B. Schneider (Eds.), Workplace flexibility: Realigning 20thcentury jobs for a 21st-century workforce (pp. 14-42). Ithaca, NY: Cornell University Press.

Bianchi, S. M., Robinson, J. P., \& Milkie, M. A. (2006). The changing rhythm of American family life. New York: Russell Sage Foundation.

Blair-Loy, M. (2003). Competing devotions. Cambridge: Harvard University Press.

Boswell, W. R. \& Olson-Buchanan, J. B. (2007). The use of communication technologies after hours: The role of work attitudes and work-life conflict. Journal of Management, 33, 592610. 
Brett, J. M. \& Stroh, L. K. (2003). Working 61 plus hours a week: Why do managers do it? Journal of Applied Psychology, 88, 67-78.

Byron, K. (2005). A meta-analytic review of work-family conflict and its antecedents. Journal of Vocational Behavior, 67, 169-198.

Carayon, P. \& Zijlstra, F. R. (1999). Relationship between job control, work pressure and strain. Studies in the USA and The Netherlands. Work \& Stress, 13, 32-48.

Chesley, N. (2005). Blurring boundaries? Linking technology use, spillover, individual distress, and family satisfaction. Journal of Marriage and the Family, 67, 1237-1248.

Clark, S. C. (2000). Work/family border theory: A new theory of work/family balance. Human Relations, 53, 747-770.

Coltrane, S. (2000). Research on household labor: Modeling and measuring the social embeddedness of routine family work. Journal of Marriage and Family, 62, 1208-1233.

Coontz, S. (1992). The way we never were: American families and the nostalgia trap. New York, NY: Basic Books.

Coser, L. (1974). Greedy institutions. New York, NY: Free Press.

Craig, L.\& Powell, A. (2011). Non-standard work schedules, work-family balance and the gendered division of childcare. Work, Employment \& Society, 25, 274-291.

Craig, L. \& Bittman, M. (2008). The incremental time costs of children: An analysis of children's impact on adult time use in Australia. Feminist Economics, 14, 59-88.

Craig, L. (2006). Does father care mean fathers share? A comparison of how mothers and fathers in intact families spend time with children. Gender and Society, 20, 259-281.

Craig, L. (2007). Is there really a second shift, and if so, who does it? A time-diary investigation. Feminist Review, 86, 149-170. 
Curtin, R., Presser, S., \& Singer, E. (2000). The effects of response rate changes on the index of consumer sentiment. Public Opinion Quarterly, 64, 413-428.

Darrah, C. N., Freeman, J. M., \& English-Lueck, J. A. (2007). Busier than ever! Why American families can't slow down. Stanford, CA: Stanford University Press.

Desrochers, S., Hilton, J. M., \& Larwood, L. (2005). Preliminary validation of the work-family integration-blurring scale. Journal of Family Issues, 26, 442-466.

Diestel, S. \& Schmidt, K. H. (2009). Mediator and moderator effects of demands on self-control in the relationship between work load and indicators of job strain. Work \& Stress, 23, 60-79.

Duxbury, L., Higgins, C., \& Neufeld, D. (1998). Telework and the balance between work and family: Is telework part of the problem or part of the solution? In M. Igbaria \& M. Tan (Eds.), The Virtual Workplace (pp. 218-255 ). Hershey, PA: Idea.

Duxbury, L., Lyons, S., \& Higgins, C. (2008). Too much to do, and not enough time: An examination of role overload. In K. Korabik, D. S. Lero, \& D. L. Whitehead (Eds.), Handbook of Work-Family Integration: Research, Theory, and Best Practices (Pp. 125-140) Academic Press/Elsevier.

Economist. (2006). The new organisation. The Economist. http://www.economist.com/node/5380483. Accessed 23 January 232013.

Elliott, J. R. \& Smith, R. A. (2004). Race, gender and workplace power. American Sociological Review, 69, 365-386.

Families and Work Institute. (2008). National study of the changing workforce. New York: Alfred P. Sloan Foundation.

Frenkel, S., Korczynski, M., Donoghue, L., \& Shire, K. (1995). Re-constituting work: Trends toward knowledge work and info-normative control. Work, Employment \& Society, 9, 773-796. 
Gajendran, R. S. \& Harrison, D. (2007). The good, the bad, and the unknown about telecommuting: Meta-analysis of psychological mediators and individual consequences. Journal of Applied Psychology, 92, 1524-1541.

Galinsky, E., Bond, J. T., Kim, S. S, Backon, L., Brownfield, E., \& Sakai, K. (2005). Overwork in America: When the way we work becomes too much. New York: Families and Work Institute.

Galinsky, E., Aumann, K., \& Bond, J. (2008). The National Study of the Changing Workforce 2008: Times are changing: Gender and generation at work and at home. New York, NY: Families and Work Institute.

Glavin, P. \& Schieman. (2012). Work-family role blurring and work-family conflict: The moderating influence of job resources and job demands. Work and Occupations, 39, 71-98.

Golden, L. (2001). Flexible work schedules: What are workers trading off to get them? Monthly Labor Review, 124, 50-67.

Green, T. K. (2005). Work culture and discrimination. California Law Review, 93, 623-658.

Greenhaus, J. H. \& Beutell, N. J. (1985). Sources of conflict between work and family roles. The Academy of Management Review, 101, 76-88.

Grotto, A. \& Lyness, K. (2010). The costs of today's jobs: Job characteristics and organizational supports as antecedents of negative spillover. Journal of Vocational Behavior, 76, 395-405.

Groves, R. M. (2006). Nonresponse rates and nonresponse bias in household surveys.Public Opinion Quarterly, 70, 646-675.

Hackman, R. J. \& Oldham, G. R. (1980). Work redesign. Reading, MA: Addison-Wesley. Hackman, R. J. \& Oldham, G. R. (1975). Development of the job diagnostic survey. Journal of Applied Psychology, 60, 159-170. 
Härmä, M. (2006). Work hours in relation to work stress, recovery and health. Scandinavian Journal of Work Environment Health, 32, 502-514.

Hays, S. (1996). The cultural contradictions of motherhood. New Haven, CT: Yale University Press.

Heisz, A. \& Larochelle-Cote, S. (2006). Summary of: Work hours instability in Canada. Ottawa: Statistics Canada.

Hill, J. E., Hawkins, A. J., Miller, B. C. (1996). Work and family in the virtual office: Perceived influences of mobile telework. Family Relations, 34, 293-301.

Hill, J. E., Hawkins, A. J., Ferris, M., \& Weitzman, M. (2001). Finding an extra day a week: The positive influence of perceived job flexibility on work and family life balance. Family Relations, 50, 49-58.

Hill, J. E., Carroll, S. J., Jones, B. L., Buswell, L. A., Fackrell, T. A. \& Galovan, A. M. (2011). Temporal workplace flexibility and associated work-life outcomes for professionals. In S. Kaiser, M. Ringlstetter, D.R. Eikhof, \& M. Pina Cunha (Eds.), Creating Balance? International Perspectives on the Work-Life Integration of Professionals (pp. 209-223) Berlin/Heidelberg: Springer Verlag.

Hochschild, A. R. (1997). The time bind: When work becomes home and home becomes work. New York, NY: Metropolitan Books.

Ironmonger, D. (2004). Bringing up Bobby and Betty: The inputs and outputs of childcare time. In N. Folbre \& M. Bittman (Eds.), Family Time: The Social Organization of Care (pp. 93-109) New York, NY: Routledge.

Jacobs, J. A. \& Gerson, K. (2004). The time divide: Work family and gender inequality. Cambridge: Harvard University Press. 
Kalleberg, A. L. (2011). Good jobs, bad jobs: The rise of polarized and precarious employment systems in the United States 1970s-2000s. New York: Russell Sage Foundation, American Sociological Association Rose Series in Sociology.

Karasek, R. A. \& Theorell, T. (1990). Healthy work: Stress, productivity, and the reconstruction of working life. New York, NY: Basic Books.

Karasek, R.A. (1979). Job demands, job decision latitude, and mental strain: Implications for job redesign. Administrative Science Quarterly, 24, 285-308.

Kelly, E. L. \& Moen, P. (2007). Rethinking the clockwork of work: Why schedule control may pay off at work and at home. Advances in Developing Human Resources, 9, 487-506.

Kopelman, R. E., Greenhaus, J. H. \& Connolly, T. (1983). A model of work, family, and interrole conflict: A construct validation study. Organizational, Behavior, and Human Performance, $32,198-215$.

Korabik, K., McElwain, A., \& Chappell, D. B. (2008). Integrating gender-related issues into research on work and family. In K. Korabik, D. S. Lero, and D. L. Whitehead (Eds.), Handbook of Work-Family Integration: Research, Theory, and Best Practices, edited by (pp. 215-232) London: Elsevier.

Kristensen, T. S., Bjorner, J. B., Christensen, K., \& Borg, V. (2004). The distinction between work pace and working hours in the measurement of quantitative demands at work. Work \& Stress, $18,305-22$.

Lambert, S. J. (1990). Processes linking work and family: A critical review and research agenda. Human Relations, 43, 239-257.

Lareau, A. (2003). Unequal childhoods: Class, race, and family life. Berkeley, CA: University of California Press. 
Lee, Y. S. \& Waite, L. J. (2005). Husbands' and wives' time spent on housework: A comparison of measures. Journal of Marriage and Family, 67, 328-336.

Lyness, K. S., Gornick, J. C., Stone, P., \& Grotto, A. G. (2012). It's all about control: Worker control over schedule and hours in cross-national cotext. American Sociological Review, 77(6), 1023-1049.

MacEachen, E., Polzer, J., \& Clarke, J. (2008). 'You are free to set your own hours': Governing worker productivity and health through flexibility and resilience. Social Science \& Medicine, 66, 1019-1033.

Malone, T. W. 2004. The future of work. Boston, MA: Harvard Business School Press.

Matthews, R., Barnes-Farrell, J., \& Bulger, C. (2010). Advancing measurement of work and family domain boundary characteristics. Journal of Vocational Behavior, 77, 447-460.

Mattingly, M. \& Sayer, L. C. (2006). Under pressure: Gender differences in the relationship between free time and feeling rushed. Journal of Marriage and Family, 68, 205-221.

Maume, D. \& Bellas, M. (2001). The overworked American or the time bind? Assessing competing explanations for time spent in paid labor. American Behavioral Scientist, 44, 1137-1156.

Maume, David J. and David A. Purcell. (2007). The 'over-paced' American: Recent trends in the intensification of work. Research in the Sociology of Work, 17, 251-283.

Mauno, S., Kinnunen, U. \& Ruokolainen, M. (2006). Exploring work-and organization-based resources as moderators between work-family conflict, well-being, and job attitudes. Work and Stress, 20, 210-233.

Medalia, C. \& Jacobs. (2008). The work week for individuals and families in 29 countries. In R. J. Burke \& C. L. Cooper (Eds.), The long work hours culture: Causes, consequences and choices, (pp. 137-57). Bingley, UK: Emerald Group Publishing. 
Merkle, D. \& Edelman, M. (2002). Nonresponse in exit polls: A comprehensive analysis. In R. M. Groves, D. A. Dillman, J. L. Eltinge, \& R. J. A. Little (Eds.), Survey nonresponse (pp. 24358). New York: Wiley.

Milkie, M. A. \& Peltola, P. (1999). Gender and the work-family balancing act. Journal of Marriage and the Family, 61, 476-490.

Mills, M. \& Täht, K. (2010). Nonstandard work schedules and partner quality: Quantitative and qualitative findings. Journal of Marriage and Family, 72, 860-875.

Mirowsky, J. \& Ross, C. E. (2003). Social causes of psychological distress. $2^{\text {nd }}$ edition. Hawthorne, New York: Aldine De Gruyter.

Mirowsky, J. (2013). Analyzing associations between mental health and social circumstances. In C. Aneshensel, J. Phelan, A. Bierman (Eds.), Handbook of the sociology of mental health, $2^{\text {nd }}$ edition ( pp. 143-165). New York, NY: Springer.

Moen, P. \& Yu, Y. (2000). Effective work-life strategies: Working couples, work conditions, gender, and life quality. Social Problems, 47, 291-326.

Morrison, D. L., Cordery, J. L., Girardi, A., \& Payne, R. (2005). Job design, opportunities for skill utilisation and job-related affective well-being. European Journal of Work and Organizational Psychology, 14, 59-80.

Nelson, M. (2010). Parenting out of control: Anxious parents in uncertain times. New York, NY: New York University Press.

Newell, S., Robertson, M., Scarborough, H. \& Swan, J. (2002). Managing knowledge work. Palgrave, UK: Basingstoke.

Nippert-Eng, C. (1996). Home and work. Chicago: University of Chicago Press. 
Offer, S. \& Schneider, B. (2011). Revisiting the gender gap in time--use patterns: Multitasking and well-being among mothers and fathers in dual-earner families. American Sociological Review, 76, 809-833.

Olson-Buchanan, J. B. \& Boswell, W. R. (2006). Blurring boundaries: Correlates of integration and segmentation between work and nonwork. Journal of Vocational Behavior, 68, 432445.

Pearlin, L. I. (1983). Role strains and personal stress. In H. Kaplan (Ed.), Psychosocial stress: Trends in theory and research (pp. 3-32). New York: Academic Press.

Presser, H. B. (1994). Employment schedules among dual-earner spouses and the division of household labor by gender. American Sociological Review, 59, 348-364.

Raghuram, S. \& Wiesenfeld, B. (2004). Work-nonwork conflict and job stress among virtual workers. Human Resource Management, 43, 259-277.

Redman, T., Snape, E., Ashurst, C. (2009). Location, location, location: Does place of work really matter? British Journal of Management, 20, S171-S181.

Reskin, B. F. \& Ross, C. E. (1992). Job, authority, and earnings among managers: The continuing significance of sex. Work and Occupations, 19, 342-365.

Roehling, P. V., Moen, P., \& Batt, R. (2003). Spillover. In P. Moen (Ed.), It's about time: Couples and careers (pp. 101-121). Cornell University Press: Ithaca.

Roxburgh, S. (2002). Racing through life: The distribution of time pressures by roles and role resources among full-time workers. Journal of Family and Economic Issues, 23, 121-45.

Sayer, L. C. (2007a). More work for mothers? Trends and gender differences in multitasking. In T. van der Lippe \& Pascale Peters (Eds.), Competing claims in work and family life (pp. 4155) Cheltenham, UK: Edward Elger. 
Sayer, L. C. (2007b). Gender differences in the relationship between long employee hours and multitasking. In B.A. Rubi (Ed.), Workplace temporalities: Research in the sociology of work, Vol. 17 (pp. 405-435), Oxford, UK: Elsevier.

Schieman, S. \& Young, M. (2010a). Is there a downside to schedule control for the work-family interface? Journal of Family Issues, 31, 1391-1414.

Schieman, S. \& Young, M. 2010b. The demands of creative work: Implications for the stress in the work-family interface. Social Science Research, 39, 246-259.

Schieman, S. \& Glavin, P. (2008). Trouble at the border? Gender, flexible work conditions, and the work-home interface. Social Problems, 55, 590-611.

Schieman, S. \& Glavin, P. (2011). Education and work-family conflict: Explanations, contingencies, and mental health consequences. Social Forces, 89, 1341-1362.

Schieman, S. \& Reid, S. (2008). Job authority and interpersonal conflict in the workplace. Work and Occupations, 35, 296-326.

Schieman, S., Milkie, M. A., \& Glavin, P. (2009). When work interferes with life: Work-nonWork interference and the influence of work-related demands and resources. American Sociological Review, 74, 966-988.

Schieman, S., Kurashina, Y., \& Gundy, K. V. (2006). The nature of work and the stress of higher status. Journal of Health and Social Behavior, 47, 242-257.

Schieman, S. (2010). Suppression effects in social stress research and their implications for the stress process model. In W.R. Avison, C. S. Aneshensel, S. Schieman, and B. Wheaton (Eds.), Advances in the conceptualization and study of the stress process: Essays in honor of Leonard I. Pearlin (pp. 53-70). New York, NY: Springer.

Schieman, S. (2013). Job-related resources and the pressures of working life. Social Science Research, 2, 271-282. 
Schneider, B. (2009). Method differences in measuring working families' time. Social Indicators Research, 93, 105-110.

Schneider, B. \& Waite, L. (2005). Being together, working apart: Dual career families and the work-life balance. Cambridge, UK: Cambridge University Press.

Shih, J. (2004). Project time in Silicon Valley. Qualitative Sociology, 27(2), 223-245.

Shockley, K. M. \& Allen, T. (2007). When flexibility helps: Another look at the availability of flexible work arrangements and work-family conflict. Journal of Vocational Behavior, 71, 479-493.

Smith, R. A. (2002). Race, gender, and authority in the workplace. Annual Review of Sociology, $28,509-542$.

Smith, V. (1997). New forms of work organization. Annual Review of Sociology, 23, 315-39.

Spink, A., Cole, C. \& Waller, M. (2008). Multitasking behavior. Annual Review of Information Science and Technology, 42, 93-118.

Steiber, N. (2009). Reported levels of time-based and strain-based conflict between work and family roles in Europe: A multilevel approach. Social Indicators Research, 93, 469-488.

Tausig, Mark \& Fenwick, R. (2011). Work and mental health in social context. Springer: New York.

Thompson, C. A. \& Prottas, D. (2006). Relationships among organizational family support, job autonomy, perceived control, and employee well-being. Journal of Occupational Health Psychology, 11, 100-118.

Valcour, M. P. (2007). Work-based resources as moderators of the relationship between work hours and satisfaction with work-life balance. Journal of Applied Psychology, 92, 1512-1523.

van den Broeck, A., Vansteenkiste, M., Witte, H. D., Soenens, B., \& Lens, W. (2010). Capturing autonomy, competence, and relatedness at work: Construction and initial validation of the 
work-related basic need satisfaction scale. Journal of Occupational and Organizational Psychology, 83, 981-1002

van der Doef, M. \& Maes, S. (1999). The job demand-control (-support) model and psychological well-being: A review of 20 years of empirical research. Work and Stress, 13, 87-114.

Vosko, L. F. (2000). Temporary work: The gendered rise of a precarious employment relationship. Toronto: University of Toronto Press.

Voydanoff, P. (2005). Consequences of boundary-spanning demands and resources for work-tofamily conflict and perceived stress. Journal of Occupational Health Psychology, 10, 491503.

Voydanoff, P. (2007). Work, family, and community: Exploring interconnections. Mahwah, New Jersey: Routledge Publishing.

Wharton, A. S. \& Blair-Loy, M. (2006). Long work hours and family life: A cross-national study of employees' concerns. Journal of Family Issues, 27, 415-436

Winship, Christopher \& Mare, R. D. (1992). Models for sample selection bias. Annual Review of Sociology, 18, 327-350.

Young, M. \& Schieman, S. (2012). When hard times take a toll: The distressing consequences of economic hardship and life events within the family-work interface. Journal of Health and Social Behavior, 53(1), 84-98.

Zedeck, S. (1992). Work, families, and organizations. San Francisco: Jossey-Bass

Zick, C. D. \& Bryant, K. W. (1996). A new look at parents' time spent in child care: Primary and secondary time use. Social Science Research, 25, 260-280. 
TABLE 1. Descriptive Statistics for Study Variables for CAN-WSH $(N=5,809)$ and NSCW $(N=3,484)$

\begin{tabular}{|c|c|c|c|c|c|c|}
\hline \multirow[b]{2}{*}{ Variable } & \multicolumn{3}{|c|}{ CAN-WSH } & \multicolumn{3}{|c|}{ NSCW } \\
\hline & Mean & SD & Range & Mean & SD & Range \\
\hline Multitasking & .31 & - & $0-1$ & .33 & - & $0-1$ \\
\hline \multicolumn{7}{|l|}{ Social Statuses and Demographics } \\
\hline Women & .48 & - & $0-1$ & .47 & - & $0-1$ \\
\hline Age & 39.93 & 13.57 & $18-72$ & 41.71 & 13.27 & $18-81$ \\
\hline Married & .38 & - & $0-1$ & .59 & - & $0-1$ \\
\hline Number of Children & .68 & - & $0-1$ & .77 & - & $0-1$ \\
\hline Less than High School & .07 & - & $0-1$ & .11 & - & $0-1$ \\
\hline High School & .20 & - & $0-1$ & .31 & - & $0-1$ \\
\hline Some College & .16 & - & $0-1$ & .21 & - & $0-1$ \\
\hline Associate Degree & .12 & - & $0-1$ & .08 & - & $0-1$ \\
\hline College Degree & .32 & - & $0-1$ & .20 & - & $0-1$ \\
\hline Graduate/Professional Degree & .12 & - & $0-1$ & .10 & - & $0-1$ \\
\hline$\$ 25,000$ or less & .27 & - & $0-1$ & .36 & - & $0-1$ \\
\hline$\$ 25,001$ to $\$ 50,000$ & .32 & - & $0-1$ & .35 & - & $0-1$ \\
\hline$\$ 50,001$ to $\$ 75,000$ & .18 & - & $0-1$ & .13 & - & $0-1$ \\
\hline$\$ 75,001$ to $\$ 100,000$ & .11 & - & $0-1$ & .05 & - & $0-1$ \\
\hline More than $\$ 100,000$ & .08 & - & $0-1$ & .05 & - & $0-1$ \\
\hline \multicolumn{7}{|l|}{ Employment Type } \\
\hline Executive/Professional & .36 & - & $0-1$ & .33 & - & $0-1$ \\
\hline Owner & .06 & - & $0-1$ & .05 & - & $0-1$ \\
\hline Self-employed & .16 & - & $0-1$ & .15 & - & $0-1$ \\
\hline Supervisor & .43 & - & $0-1$ & .35 & - & $0-1$ \\
\hline Work Location and Schedule & & & $0-1$ & & & \\
\hline Work at Home & .08 & - & $0-1$ & .07 & - & $0-1$ \\
\hline At Fixed Location & .73 & - & $0-1$ & .73 & - & $0-1$ \\
\hline Other Work Location & .19 & - & $0-1$ & .21 & - & $0-1$ \\
\hline Regular Daytime Shift & .63 & - & $0-1$ & .72 & - & $0-1$ \\
\hline Night Shift & .07 & - & $0-1$ & .07 & - & $0-1$ \\
\hline Rotating/Split Shift & .12 & - & $0-1$ & .09 & - & $0-1$ \\
\hline Flexible/Variable Shift & .15 & - & $0-1$ & .13 & - & $0-1$ \\
\hline Some Other Shift & .02 & - & $0-1$ & .02 & - & $0-1$ \\
\hline Job-Related Demands & & & $0-1$ & & & $0-1$ \\
\hline Long Work Hours & .17 & - & $0-1$ & .30 & - & $0-1$ \\
\hline Second Job & .09 & - & $0-1$ & .19 & - & $0-1$ \\
\hline Job Pressure & 2.96 & 1.10 & $1-5$ & 2.93 & 1.00 & $1-5$ \\
\hline Work Contact & 2.34 & 1.08 & $1-5$ & 2.89 & 2.12 & $1-8$ \\
\hline \multicolumn{7}{|l|}{ Job-Related Resources } \\
\hline Schedule Control & 2.98 & 1.35 & $1-5$ & 3.13 & 1.40 & $1-5$ \\
\hline Job Autonomy & 2.89 & .81 & $1-4$ & 3.08 & .78 & $1-4$ \\
\hline Challenging Work & 3.29 & .68 & $1-4$ & 3.14 & .59 & $1-4$ \\
\hline
\end{tabular}

Notes: Proportions presented for categorical variables. All descriptives based on weighted data. 
TABLE 2. Logistic Regression of Multitasking on Job Demands and Resources (CAN-WSH, N=5,809)

\begin{tabular}{|c|c|c|c|c|c|}
\hline & Model 1 & Model 2 & Model 3 & Model 4 & Model 5 \\
\hline \multirow{2}{*}{\multicolumn{6}{|c|}{$\begin{array}{l}\text { Social Statuses and } \\
\text { Demographics }\end{array}$}} \\
\hline & & & & & \\
\hline \multicolumn{6}{|l|}{$\begin{array}{l}\text { Demographics } \\
\text { Women }\end{array}$} \\
\hline Age & 1.003 & $.990 * *$ & .997 & $.988^{* * *}$ & .996 \\
\hline Married & 1.050 & 1.029 & .972 & 1.032 & .978 \\
\hline Number of Children & $1.093^{*}$ & $1.093^{*}$ & 1.069 & $1.086^{*}$ & 1.062 \\
\hline Less than High School ${ }^{a}$ & 1.069 & .961 & 1.009 & .981 & 1.018 \\
\hline Some College $^{a}$ & 1.268 & 1.148 & .973 & 1.181 & .998 \\
\hline Associate Degree $^{a}$ & 1.030 & .945 & .928 & .92 & .905 \\
\hline College Degree $^{a}$ & $1.700^{* * * *}$ & $1.522 * *$ & 1.304 & $1.521^{* *}$ & 1.300 \\
\hline Graduate Degree $^{a}$ & $2.713 * * *$ & $2.093 * * *$ & $1.616^{* *}$ & $2.038 * * *$ & $1.575^{* *}$ \\
\hline$\$ 25,000$ or less ${ }^{b}$ & 1.010 & .914 & 1.013 & .958 & 1.047 \\
\hline$\$ 50,001$ to $\$ 75,000^{b}$ & $1.281 *$ & $1.263 *$ & 1.145 & 1.239 & 1.125 \\
\hline$\$ 75,001$ to $\$ 100,000^{b}$ & $1.634 * * *$ & $1.583 * * *$ & 1.159 & $1.547 * * *$ & 1.145 \\
\hline More than $\$ 100,000^{b}$ & $1.947 * * *$ & $1.515^{* *}$ & 1.035 & $1.513^{* *}$ & 1.057 \\
\hline \multicolumn{6}{|l|}{ Employment Type } \\
\hline Executive/Professional & - & $1.584 * * *$ & $1.348^{* *}$ & $1.494 * * *$ & $1.306^{* *}$ \\
\hline Owner & - & $1.926 * * *$ & $1.651^{* *}$ & $1.922 * * *$ & $1.692^{* *}$ \\
\hline Self-employed & - & $1.750 * * *$ & $1.798 * * *$ & $1.721 * * *$ & $1.797^{* * *}$ \\
\hline Supervisor & - & $1.419 * * *$ & .972 & $1.327 * * *$ & .931 \\
\hline \multicolumn{6}{|l|}{ Work Location/Schedule } \\
\hline Work at Home & - & $4.625 * * *$ & $4.157 * * *$ & $4.258 * * *$ & $4.029 * * *$ \\
\hline Other Work Location & - & $1.913 * * *$ & $1.533 * * *$ & $1.798 * * *$ & $1.472 * *$ \\
\hline Night Shift ${ }^{c}$ & - & .670 & .710 & .757 & .788 \\
\hline Rotating/Split Shift ${ }^{c}$ & - & .762 & $.680^{*}$ & .772 & $.691^{*}$ \\
\hline Flexible/Variable Shift ${ }^{c}$ & - & $1.384 * *$ & 1.049 & $1.420^{* *}$ & 1.094 \\
\hline Other Shift ${ }^{c}$ & - & 1.480 & 1.238 & 1.548 & 1.300 \\
\hline \multicolumn{6}{|l|}{ Job-Related Demands } \\
\hline Long Work Hours & - & - & $1.400 * *$ & - & $1.363^{* *}$ \\
\hline Second Job & - & - & $2.031 * * *$ & - & $2.050^{* * *}$ \\
\hline Job Pressure & - & - & $1.274 * * *$ & - & $1.273^{* * *}$ \\
\hline Work Contact & - & - & $2.023 * * *$ & - & $2.009^{* * *}$ \\
\hline \multicolumn{6}{|l|}{ Job-Related Resources } \\
\hline Schedule Control & - & - & - & .941 & $.916^{*}$ \\
\hline Job Autonomy & - & - & - & 1.095 & 1.115 \\
\hline Challenging Work & - & - & - & $1.433 * * *$ & $1.279^{* *}$ \\
\hline Constant & $.217 * * *$ & $.189 * * *$ & $.0174 * * *$ & $.060 * * *$ & $.008^{* * *}$ \\
\hline$\chi^{2}$ & 200.1 & 497.7 & 724.8 & 513.6 & 732.8 \\
\hline
\end{tabular}

$* p<.05 ; * * p<.01 ; * * * p<.001$ (two-tailed test).

${ }^{a}$ Compared to high school degree or GED. ${ }^{b}$ Compared to $\$ 25,001$ to $\$ 50,000 .{ }^{c}$ Compared to regular daytime shift. Note: Odds ratios presented. 
TABLE 3. Logistic Regression of Multitasking on Job Demands and Resources (NSCW, N=3,484)

\begin{tabular}{|c|c|c|c|c|c|}
\hline & Model 1 & Model 2 & Model 3 & Model 4 & Model 5 \\
\hline \multicolumn{6}{|c|}{ Social Statuses/Demographics } \\
\hline Women & .961 & 1.040 & 1.001 & 1.067 & 1.017 \\
\hline Age & .994 & $.987 * * *$ & $.991^{*}$ & $.986 * * *$ & $.990^{*}$ \\
\hline Married & 1.115 & 1.123 & 1.135 & 1.104 & 1.124 \\
\hline Number of Children & 1.052 & 1.065 & 1.060 & 1.057 & 1.054 \\
\hline Less than High School ${ }^{a}$ & $2.365 * * *$ & $2.555 * * *$ & $2.827 * * *$ & $2.566 * * *$ & $2.843 * * *$ \\
\hline Some College $^{a}$ & 1.076 & .977 & .937 & .983 & .945 \\
\hline Associate Degree $^{a}$ & .995 & .933 & .840 & .905 & .822 \\
\hline College Degree $^{a}$ & $1.777 * * *$ & $1.511 * *$ & $1.430 *$ & $1.455 * *$ & $1.389 *$ \\
\hline Graduate Degree $^{a}$ & $2.677 * * *$ & $2.070 * * *$ & $1.873 * * *$ & $1.881 * * *$ & $1.741^{* *}$ \\
\hline$\$ 25,000$ or less $^{b}$ & .957 & .944 & 1.161 & .972 & 1.179 \\
\hline$\$ 50,001$ to $\$ 75,000^{b}$ & $1.407 * *$ & $1.334 *$ & 1.203 & 1.285 & 1.186 \\
\hline$\$ 75,001$ to $\$ 100,000^{b}$ & $1.839 * * *$ & $1.570^{*}$ & 1.296 & $1.591 *$ & 1.340 \\
\hline More than $\$ 100,000^{b}$ & $2.646 * * *$ & $1.668^{*}$ & 1.388 & $1.781 * *$ & 1.478 \\
\hline \multicolumn{6}{|l|}{ Employment Type } \\
\hline Executive/Professional & - & $1.653 * * *$ & $1.454 * *$ & $1.534 * * *$ & $1.369^{* *}$ \\
\hline Owner & - & $1.544 *$ & 1.072 & $1.661 *$ & 1.144 \\
\hline Self-employed & - & $2.248 * * *$ & $1.842 * * *$ & $2.289 * * *$ & $1.862 * * *$ \\
\hline Supervisor & - & $1.581 * * *$ & 1.145 & $1.513 * * *$ & 1.113 \\
\hline \multicolumn{6}{|l|}{ Work Location/Schedule } \\
\hline Work at Home & - & $6.621 * * *$ & $6.883 * * *$ & $6.641 * * *$ & $6.888^{* * * *}$ \\
\hline Other Work Location & - & $1.719 * * *$ & $1.473 * *$ & $1.662 * * *$ & $1.435^{* *}$ \\
\hline Night Shift ${ }^{c}$ & - & .693 & .776 & .775 & .841 \\
\hline Rotating/Split Shift ${ }^{c}$ & - & 1.203 & 1.214 & 1.236 & 1.254 \\
\hline Flexible/Variable Shift ${ }^{c}$ & - & $1.544^{* *}$ & 1.262 & $1.626 * * *$ & $1.327^{*}$ \\
\hline Other Shift ${ }^{c}$ & - & .948 & .973 & 1.006 & 1.024 \\
\hline \multicolumn{6}{|l|}{ Job-Related Demands } \\
\hline Long Work Hours & - & - & $1.238^{*}$ & - & 1.180 \\
\hline Second Job & - & - & $1.319 *$ & - & $1.301 *$ \\
\hline Job Pressure & - & - & $1.857 * * *$ & - & $1.830 * * *$ \\
\hline Work Contact & - & - & $1.227 * * *$ & - & $1.226 * * *$ \\
\hline \multicolumn{6}{|l|}{ Job-Related Resources } \\
\hline Schedule Control & - & - & - & $.898 * *$ & $.912 *$ \\
\hline Job Autonomy & - & - & - & 1.020 & 1.040 \\
\hline Challenging Work & - & - & - & $1.639 * * *$ & $1.469 * * *$ \\
\hline Constant & 362 & $.227 * * *$ & $.113^{* * * *}$ & $.068 * * *$ & $.043 * * *$ \\
\hline$\chi^{2}$ & 193.9 & 411.4 & 498.8 & 435.6 & 507.6 \\
\hline
\end{tabular}

$* p<.05 ; * * p<.01 ; * * * p<.001$ (two-tailed test).

${ }^{a}$ Compared to high school degree or GED. ${ }^{b}$ Compared to $\$ 25,001$ to $\$ 50,000 .{ }^{c}$ Compared to regular daytime shift. Note: Odds ratios presented. 
APPENDIX A. Pair-Wise Correlations between Focal Variables for CAN-WSH (below the diagonal, $N=5,809$ ) and NSCW (above the diagonal, $N=3,484$ )

\begin{tabular}{|c|c|c|c|c|c|c|c|c|}
\hline & & 1 & 2 & 3 & 4 & 5 & 6 & 7 \\
\hline 1 & Long work hours & 1.00 & -.02 & .23 & .28 & .02 & .13 & .19 \\
\hline 2 & Second job & .01 & 1.00 & .03 & .10 & .04 & .05 & .06 \\
\hline 3 & Job pressures & .19 & .01 & 1.00 & .20 & -.07 & -.01 & .14 \\
\hline 4 & Contact & .29 & .06 & .30 & 1.00 & .22 & .27 & .22 \\
\hline 5 & Schedule control & .15 & .01 & -.08 & .24 & 1.00 & .45 & .24 \\
\hline 6 & Autonomy & .12 & .00 & -.04 & .21 & .44 & 1.00 & .44 \\
\hline 7 & Challenging Work & .13 & -.01 & .09 & .23 & .23 & .42 & 1.00 \\
\hline
\end{tabular}

Notes: All correlations higher than .05 are significant at the. 05 probability level. 
FIGURE 1. Education and the Probability of Work-Family Multitasking (Unadjusted and Adjusted for Employment Type, Work Location/Schedule, and Job Demands and Resources)

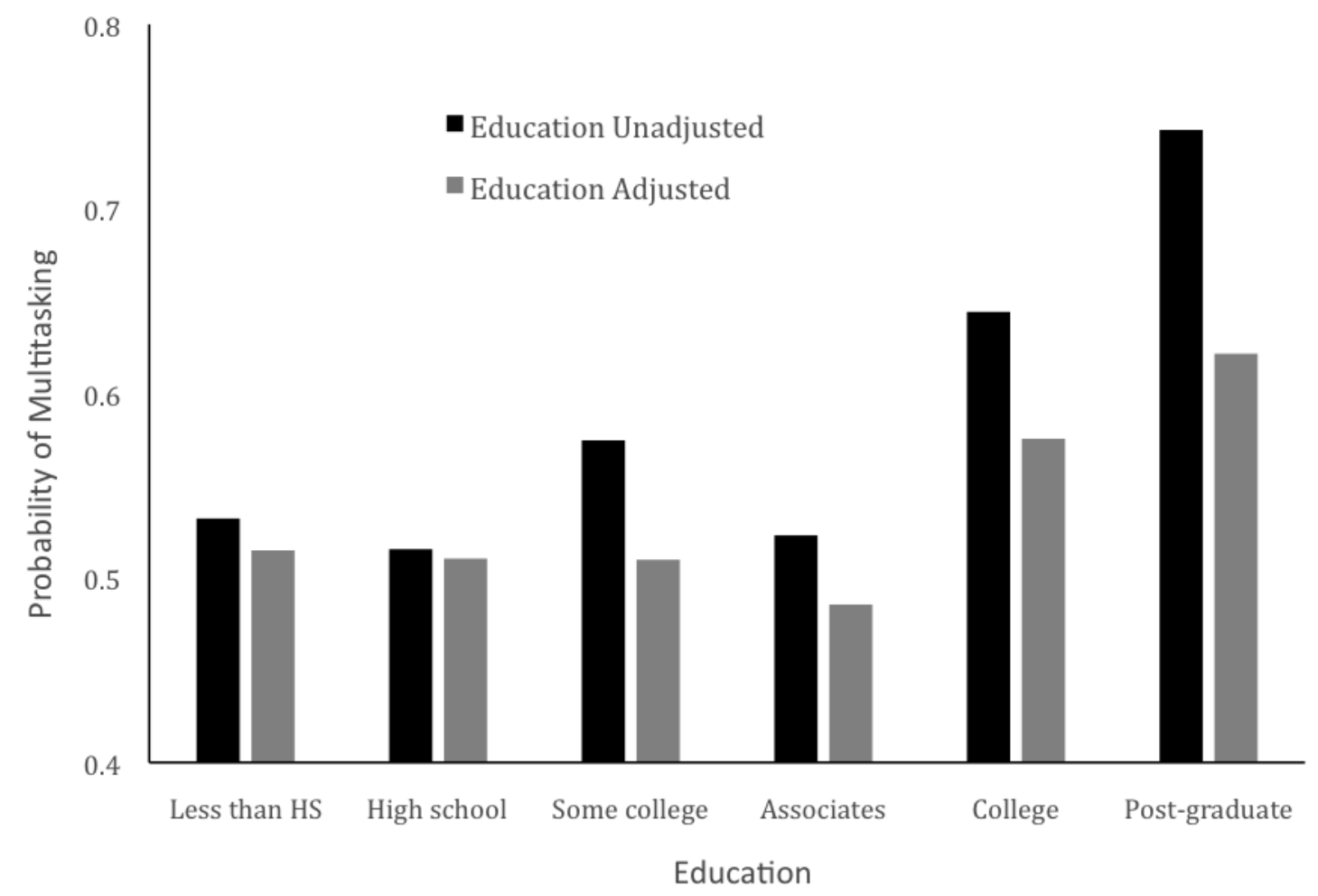

Note: The dark bars represent predicted probabilities for model 1; the lighter bars indicate predicted probabilities for model 5 adjusted for all study variables. 
FIGURE 2. Income and the Probability of Work-Family Multitasking (Unadjusted and Adjusted for Employment Type, Work Location/Schedule, and Job Demands and Resources)

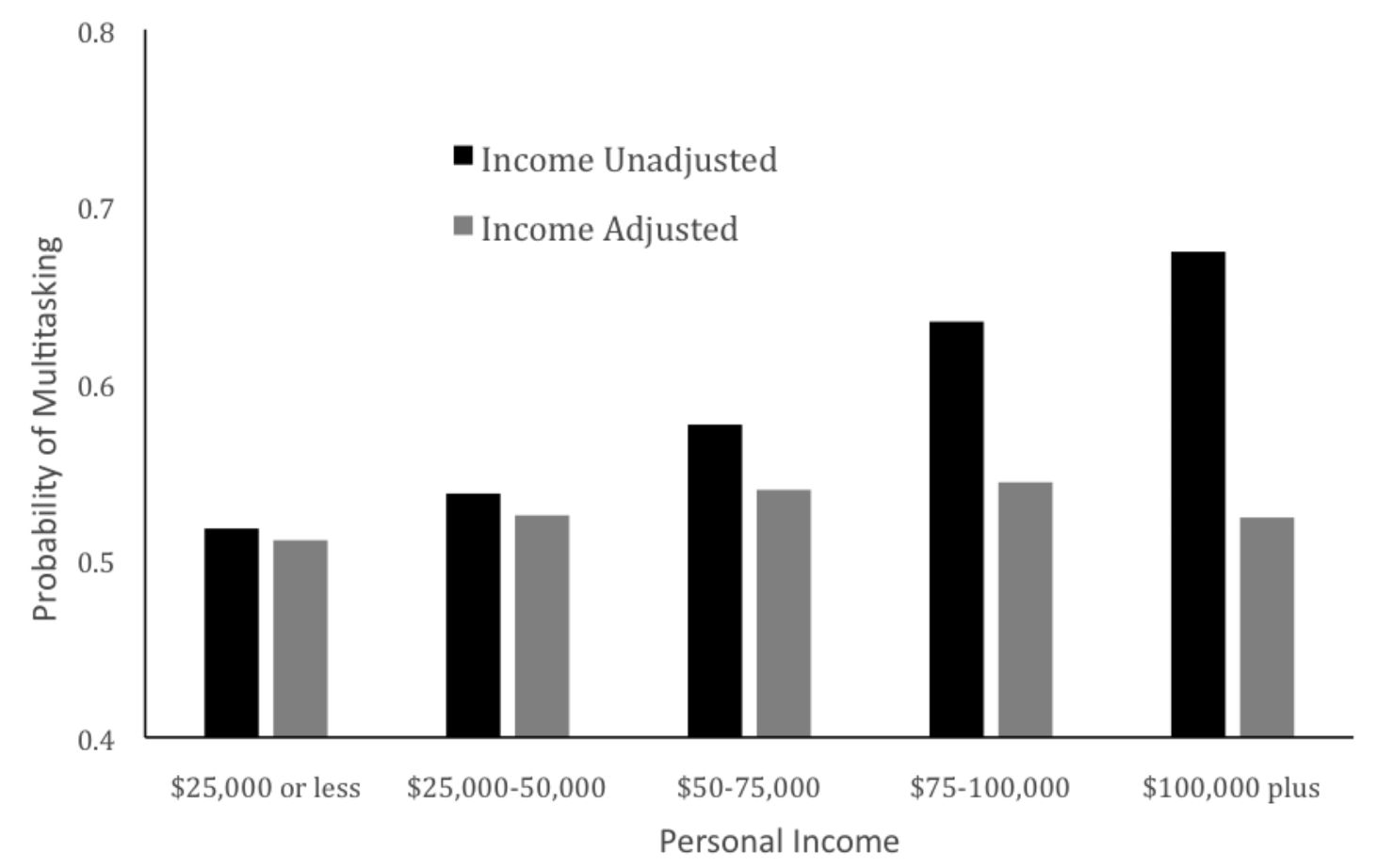

Note: The dark bars represent predicted probabilities for model 1; the lighter bars indicate predicted probabilities for model 5 adjusted for all study variables. 
FIGURE 3. Supervisor Status and the Probability of Work-Family Multitasking (Unadjusted and Adjusted for Employment Type, Work Location/Schedule, and Job Demands and Resources)

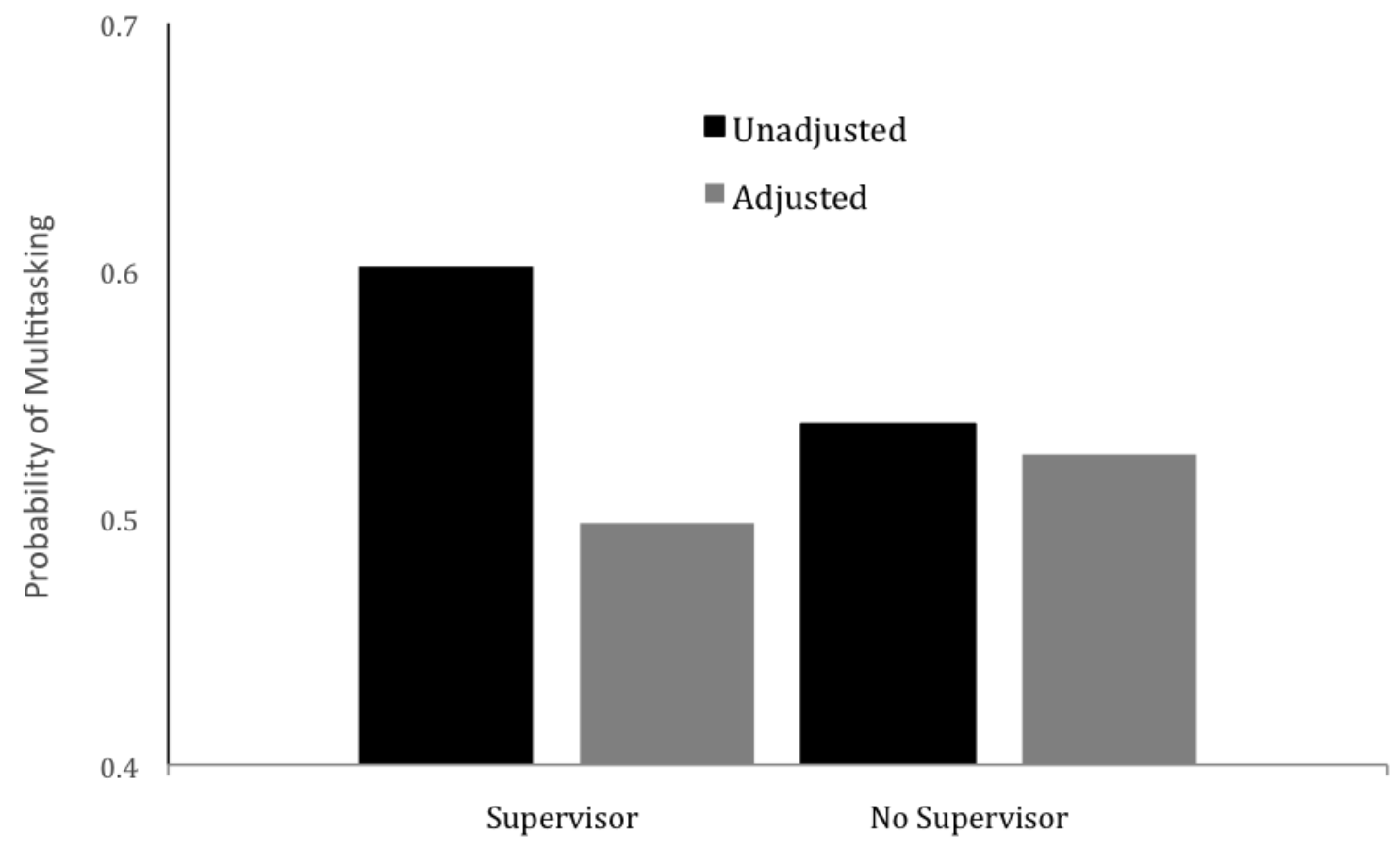

Note: The dark bars represent predicted probabilities for model 2; the lighter bars indicate predicted probabilities for model 5 adjusted for all study variables. 